\title{
Distribution of ABO and Rh Blood Groups Among Students of Some Ethnic Groups at Dilla University, Ethiopia
}

\author{
Fekadu Alemu Atire \\ Department of Biology, College of Natural and Computational Sciences, Dilla University, Dilla, Ethiopia
}

Email address:

fekealex@gmail.com

To cite this article:

Fekadu Alemu Atire. Distribution of ABO and Rh Blood Groups Among Students of Some Ethnic Groups at Dilla University, Ethiopia. International Journal of Genetics and Genomics. Vol. 3, No. 1, 2015, pp. 8-19. doi: 10.11648/j.ijgg.20150301.12

\begin{abstract}
Red Blood cells (Erythrocytes) have an inherited combination of proteins, glycol-proteins, and glycol-lipids on their surfaces. These function as antigens that enable our immune system to distinguish our own cells from foreign invaders. Part of the immune response is the production of globulins called antibodies to combat the invader. In blood typing, the antigens of Red Blood Cell surfaces are also called agglutinogens because they are partially responsible for Red Blood Cell agglutination in mismatched transfusions.A blood sample was taken from the voluntary students of Dilla University. There are differences in frequency distribution of the blood group (ABO) among the ethnic groups and administrate of the students at Dilla University. The most prevalent blood group was type O (44.49\%) followed by A (26.32 \%), B (26.32\%), and AB (2.87\%). The most prevalent Rh-positive blood group among students were type $\mathrm{O}^{+}(41.94 \%)$ followed by $\mathrm{A}^{+}(31.72 \%), \mathrm{B}^{+}$ $(26.34 \%)$, and $\mathrm{AB}^{+}(2.15 \%)$ as well as the highest Rh-negative blood groups among students were type $\mathrm{O}^{-}(65.22 \%)$ followed by $\mathrm{B}^{-}(26.08 \%), \mathrm{AB}^{-}(26.34 \%)$, and no $\mathrm{A}^{-}$blood group. Therefore, the blood type and group of Dilla University students was varies across the ethnic groups.
\end{abstract}

Keywords: Dilla University, Ethnic Groups, Red Blood Cell, Rh-Negative Blood Groups, Rh-Positive Blood Group

\section{Introduction}

The blood plays more roles than one might expect, it is involved in respiration, nutrition, waste elimination, thermoregulation, immune defense, water and acid-base balance, and internal communication. Most adults have 4 to 6 L of blood. Erythrocytes are also known as red blood cells (RBCs), leukocytes are also known as white blood cells (WBCs) and Platelets.Erythrocytes have two principal functions: (1) to pick up oxygen from the lungs and deliver it to tissues elsewhere and (2) to pick up carbon dioxide from other tissues and unload it in the lungs. An erythrocyte is a disc-shaped cell with a thick rim and a thin sunken center where the nucleus used to be. It is about $7.5 \mu \mathrm{m}$ in diameter and $2.0 \mu \mathrm{m}$ thick at the rim [1].The differences in human blood are due to the presence or absence of certain protein molecules called antigens and antibodies. Theantigensarelocatedonthe surface ofthered blood cells andthe antibodies areinthe bloodplasma.Individuals have different types and combinations of these molecules [2].

The $\mathrm{ABO}$ and $\mathrm{Rh}$ blood groups are the most important blood groups despite the long list ofseveral other blood groups discovered so far [3, 4]. ABO and Rh blood groups are the most studied blood systems among human populations due to their clinical, genetic and anthropological importance $[5,6,7]$. The grouping of $\mathrm{ABO}$ and $\mathrm{Rh}$ factor into blood groups is based on the antigenic properties on the surface membrane of the red blood cells (RBCs) [8]. The two significant blood group systems were discovered during early experiments with blood transfusions, the ABO group in 1901 and the rhesus group in 1939 [9]. Blood types A, B, AB, and $\mathrm{O}$ form the $\mathrm{ABO}$ blood group. $\mathrm{ABO}$ blood type is determined by the hereditary presence or absence of antigens $\mathrm{A}$ and $\mathrm{B}$ on RBCs. The antigens are glycol-proteins and glycol-lipids membrane proteins and phospholipids with short carbohydrate chains bonded to them. Figure 1 shows how these carbohydrates determine the $\mathrm{ABO}$ blood types. In blood typing, the antigens of RBC surfaces are also called agglutinogens because they are partially responsible for RBC agglutination in mismatched transfusions. The plasma antibodies that react against them are also called agglutinins as indicated in Figure 2[1].

The $\mathrm{Rh}$ blood group is named for the rhesus monkey, in which the Rh antigens were discovered in 1940. This group is determined by genes called $\mathrm{D}$ which has two alleles: $\mathrm{D}, \mathrm{d}$. 
Whatever other alleles a person may have, anyone with genotype DD or Dd has D antigens on his or her RBCs and is classified as $\mathrm{Rh}$-positive $\left(\mathrm{Rh}^{+}\right)$. In $\mathrm{Rh}$-negative $\left(\mathrm{Rh}^{-}\right)$people, the $\mathrm{D}$ antigen is lacking. The Rh blood type is tested by using an anti-D reagent. ABO group, anti-D antibodies are not normally present in the blood. They form only in $\mathrm{Rh}^{+}$ individuals who are exposed to $\mathrm{Rh}^{-}$blood. If an $\mathrm{Rh}^{-}$person receives an $\mathrm{Rh}^{+}$transfusion, the recipient produces anti-D. A related condition sometimes occurs when an $\mathrm{Rh}^{-}$woman carries an $\mathrm{Rh}^{+}$fetus. The first pregnancy is likely to be

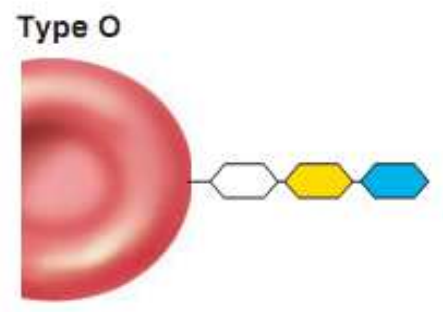

\section{Type A}
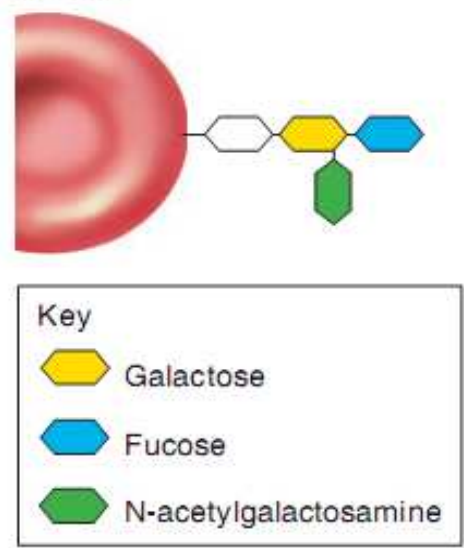

uneventful because the placenta normally prevents maternal and fetal blood from mixing. However, at the time of birth, or if a miscarriage occurs, placental tearing exposes the mother to $\mathrm{Rh}^{+}$fetal blood. She then begins to produce anti-D antibodies as indicated in Figure 3. If she becomes pregnant again with an $\mathrm{Rh}^{+}$fetus, her anti-D antibodies may pass through the placenta and agglutinate the fetal erythrocytes. Agglutinated RBCs hemolyze, and the baby is born with a severe anemia called hemolytic disease of the newborn (HDN), or erythroblastosis fetalis [1].

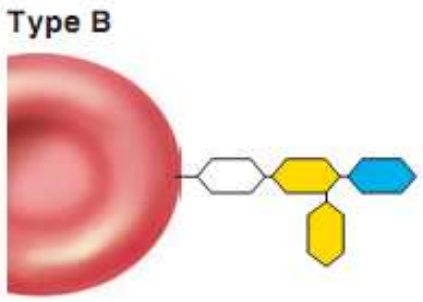

Type AB

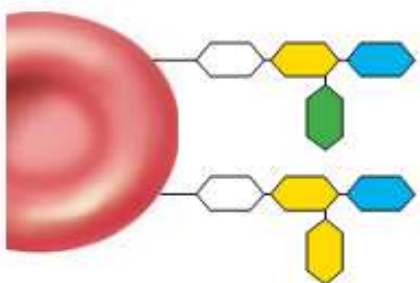

Figure 1. Chemical bases of the ABO Blood Types, the terminal carbohydrates of the antigenic glycolipids are shown. All of them end with galactose and fucose (not to be confused with fructose). In type A, the galactose also has an N-acetylgalactosamine added to it; in type B, it has another galactose; and in type $A B$, both of these chain types are present [1].

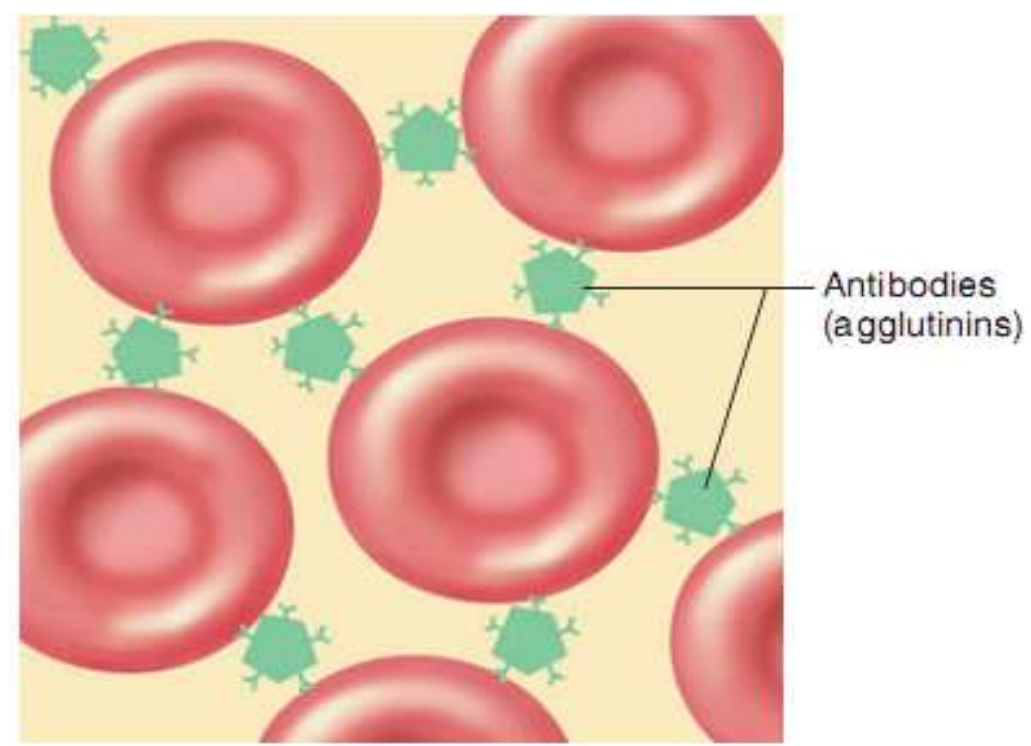

Figure 2. Agglutination of RBCs by an Antibody, Anti-A and anti-B have 10 binding sites, located at the 2 tips of each of the 5 YS, and can therefore bind multiple RBCs to each other [1]. 


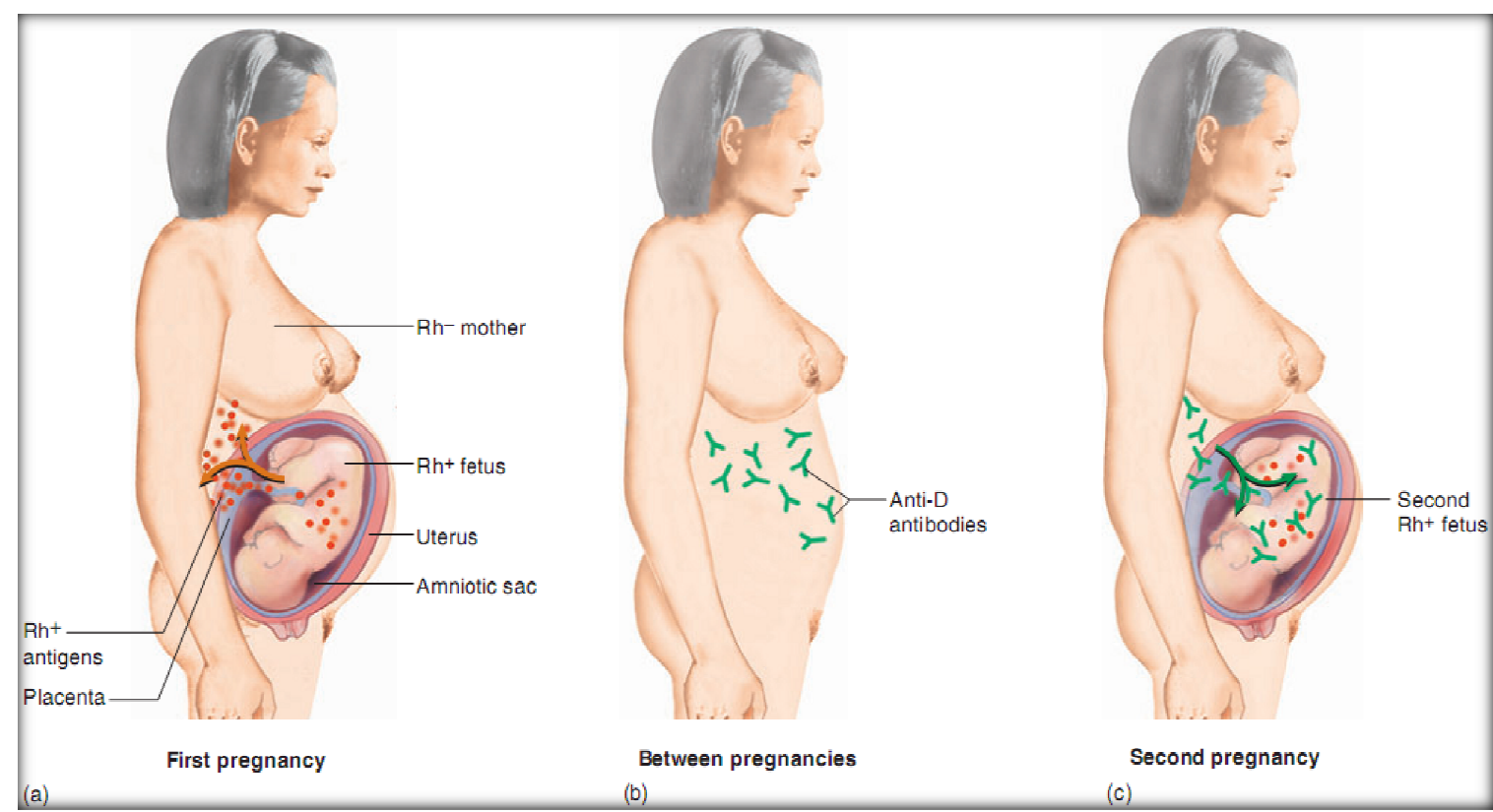

Figure 3. Hemolytic Disease of the Newborn (HDN), (a) When an Rh-woman is pregnant with an Rh fetus; she is exposed to D (Rh) antigens, especially

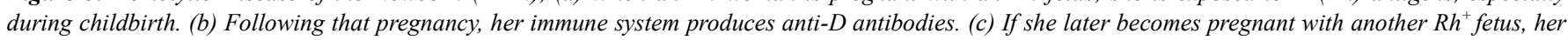
anti-D antibodies can cross the placenta and agglutinate the blood of that fetus, causing that child to be born with HDN[1].

Furthermore, the discovery of $\mathrm{ABO}$ and $\mathrm{Rh}$ blood groups has contributed immensely to blood banking services and transfusion medicine in preventing many of the immunogenetic, hematological and transfusion problems [10]. The $\mathrm{ABO}$ and $\mathrm{Rh}$ blood groups varies worldwide and are not found in equal numbers even among different ethnic groups. Among African-American $\mathrm{ABO}$ blood group, the distribution of type O, $46 \%$; type A, $27 \%$; type B, $20 \%$; and type $A B ; 7 \%$. In Caucasians in the United State, the distribution is type $\mathrm{O}$, $47 \%$; type A, $41 \%$; type B, $9 \%$; type AB, $3 \%$. Also, among Western Europeans, type O, 46\%; type A, 42\%; type B, $9 \%$; and type $\mathrm{AB}, 3 \%$ [11, 12]. Moreover, Rh-positive is documented as $95 \%$ in African-Americans, $100 \%$ in Africans whereas Rh- negative is $5.5 \%$ in South India, $5 \%$ in Nairobi, $7.3 \%$ in Lahore, $4.8 \%$ in Nigeria $[13,14]$. The $A B O$ bloodsystem wasthefirst bloodtypesystem (Landsteiner, 1900)anditisalsothemostclinicallyimportantsystemwithregard tobloodtransfusion. The blood grouping is done in laboratories by slide test which is a manual method. Most of the techniques applied are still based on the principle of interaction between antigen and antibody and subsequent agglutination of RBCs (positive result).The absence of agglutination indicates the lack of interaction (negative result) [15].

Determination of $\mathrm{ABO}$ grouping is important in pretransfusion studies of patients and donors as well as in cases of patients. There are different techniques to determine ABO grouping in the laboratory: slide, test tube and micro plate. In each technique results are interpreted based on the presence or absence of agglutination reaction. Agglutination reaction is interpreted as a positive $(+)$ test result and indicates, based on the method used, the presence of specific antigen on erythrocytes or antibody in the serum of an individual. No agglutination reaction produces a negative (-) test indicating the absence of specific antigens on erythrocytes or antibody in the serum of an individual.Apart from their importance in blood transfusion practice, the $\mathrm{ABO}$ and $\mathrm{Rh}$ blood groups are useful in population genetic studies, researching population migration patterns as well as resolving certain medico-legal issues, particularly of disputed paternity cases. In modern medicine besides their importance in evolution, their relation to disease and environment is being increasingly important $[16,17]$.

Interestingly, apart from the importance of $\mathrm{ABO}$ and $\mathrm{Rh}$ blood groups in blood transfusion practice, they are useful in population genetic studies, researching population migration pattern. It is, therefore, imperative to have information on the distribution of these blood groups in any population group that comprise different ethnic groups. This present study will be investigated to have information on the distribution of $\mathrm{ABO}$ and $\mathrm{Rh}$ blood groups among each of all Dilla University which represent all Ethiopian population (nation and nationality). This is also giving the way of selecting blood type and knowing that will be needed during marriage and accident for donating to patient and receiving from healthy individuals. Present study was focused on determination of the blood types of voluntary students of Dilla University which are coming from all ethnic groups.

\section{Materials and Methods}

\subsection{Study Siteand Sample of Population}

This study was carried out at the College of Natural and Computational Science, Departmentof Biology, in Microbiology Laboratory at Dilla University, Ethiopia, during 2014.

A total of 209 voluntary students were randomly selected 
among the all students at Dilla Universityand tested. The students were divided into 6 major ethnic groups and one administration i.e.,Amhara, Southern Nations Nationalities and Peoples (SNNP), Oromia, Gambela Peoples, Tigray, Benshangul-Gumaz and Addis Ababa ethnic groups and administrative respectively. Out of 209 voluntary students, 77 (52 males, 24 females), 71 (40 males, 31 females) and 47 (33 males, 14 females), 4 (4 males, 0 females), 3 (0 males, 3 females) 1 (0 males, 1 females $), 7$ (3males, 4 females) students were Amhara, SNNP, Oromia, Gambela Peoples, Tigray, Benshangul-Gumaz and Addis Ababa ethnic groups and administrative with mean age 22.5, range 19-26 years respectively.

\subsection{Laboratory Analyses}

\subsubsection{Blood Samples Collection and Blood Group} Determination
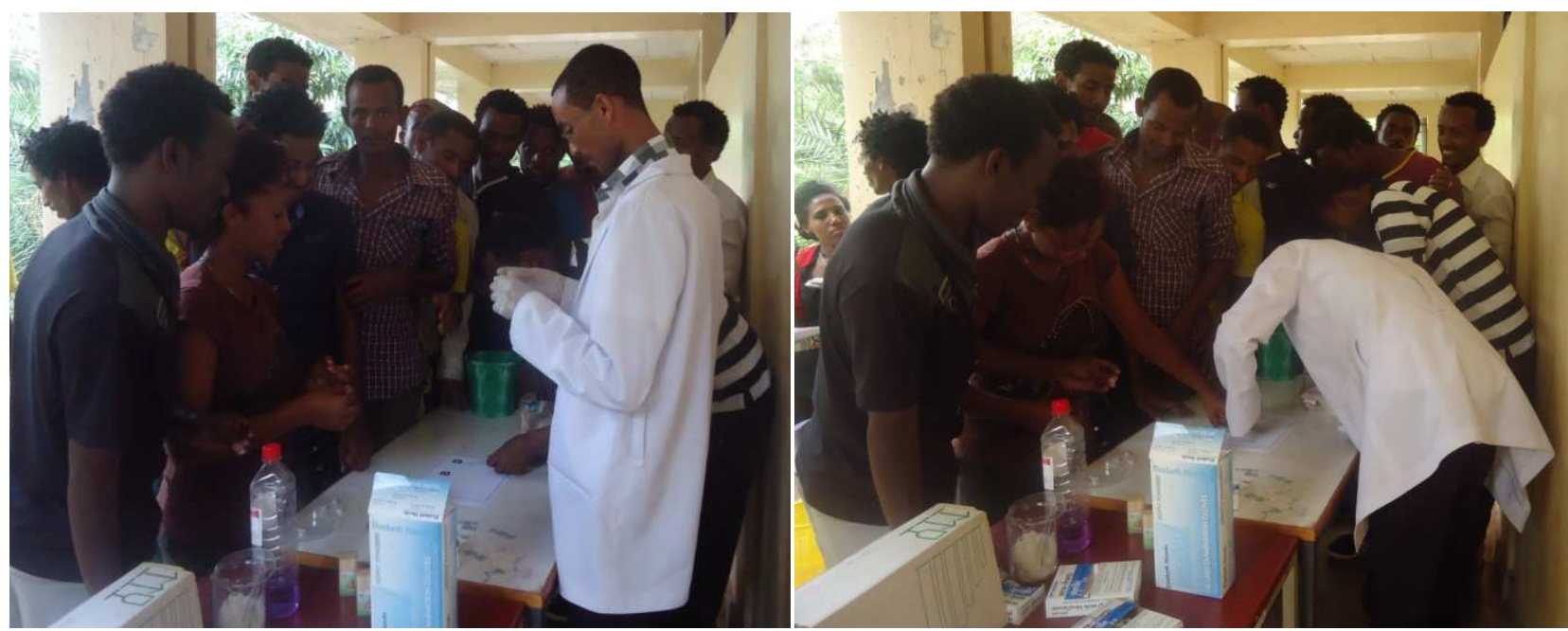

Figure 4. During blood sample taken from voluntary students.
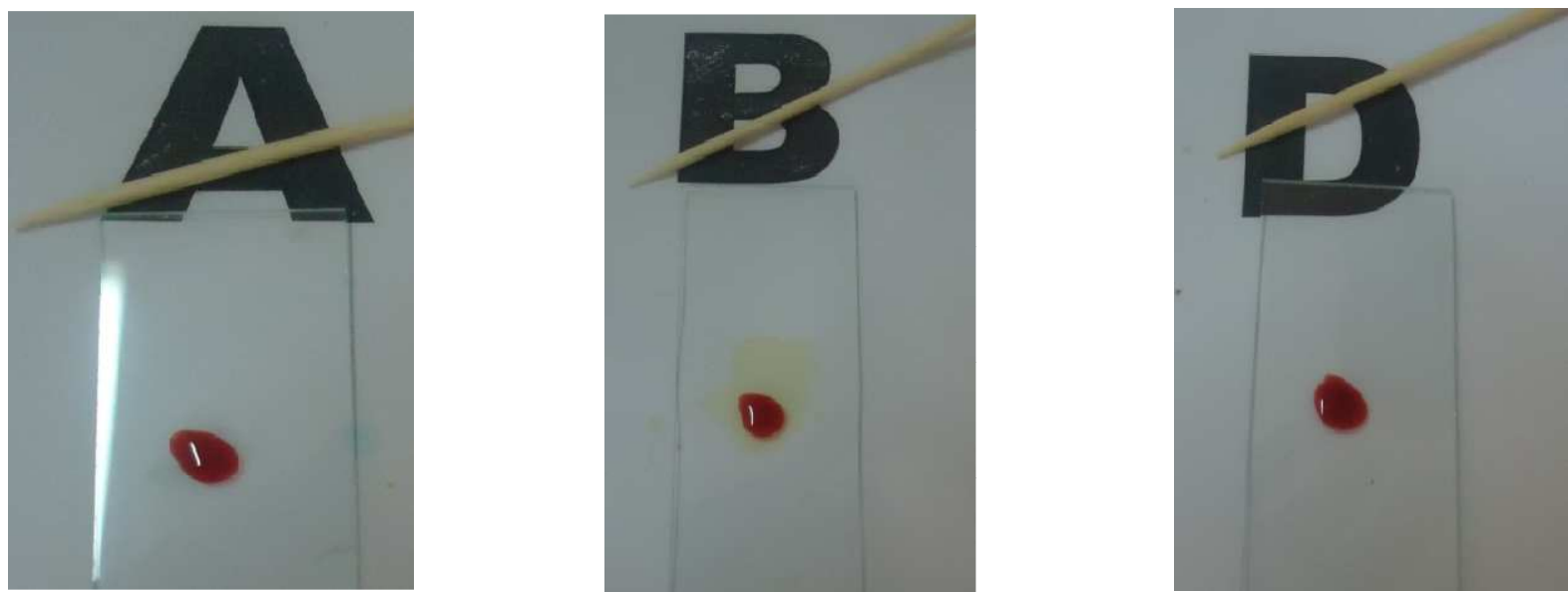

Figure 5. After blood sample taken on clean glass slide from voluntary student. 


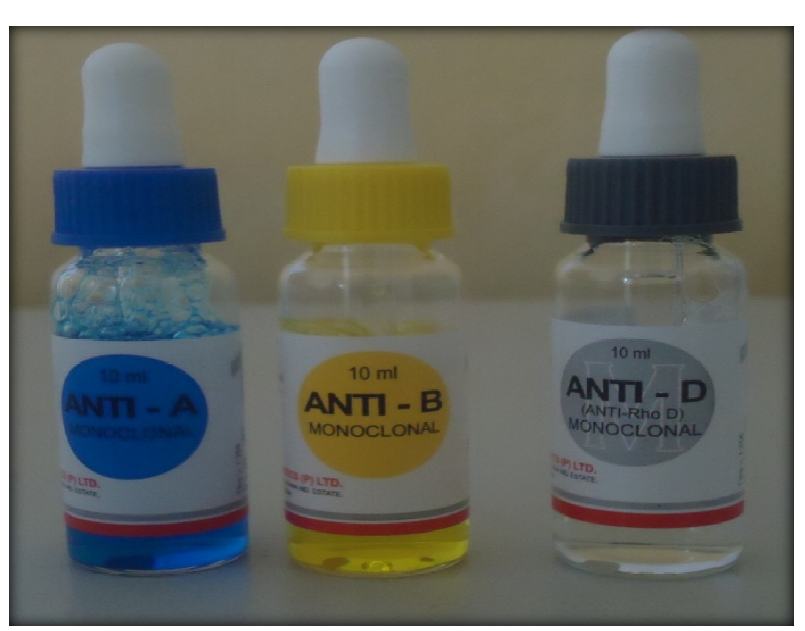

Figure 6. Anti-A, anti- B, and anti-D Monoclonal.

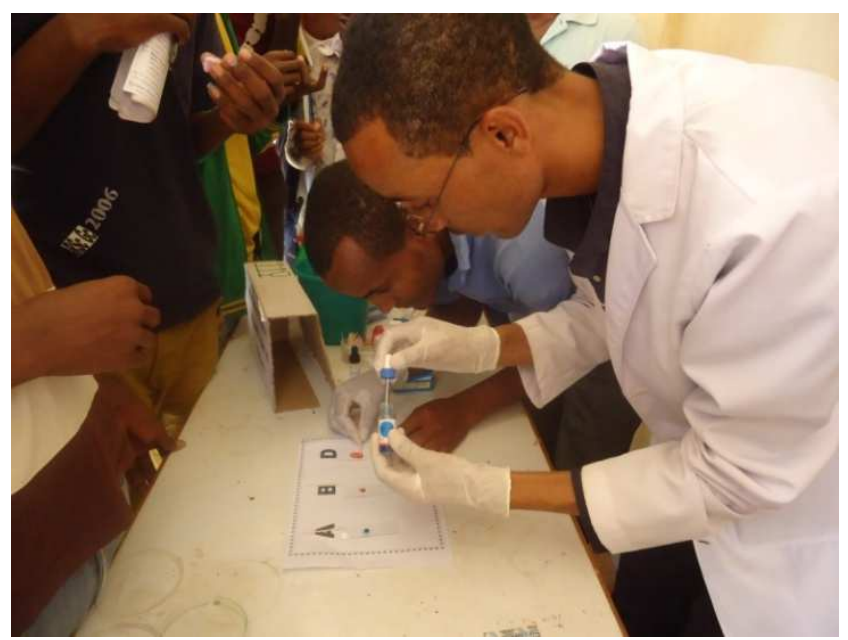

Figure7. Addition of antisera on each blood group.

\subsubsection{Observation of Blood Type and Group}

The following are the blood samples of various blood groups taken and mixed with Anti-A, Anti-B and Anti-D (Anti-Rho D) Monoclonal and observed by naked eye and under the microscope either form clumping or not.

A.A Positive Group

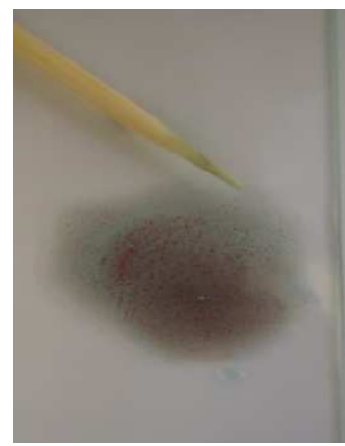

A

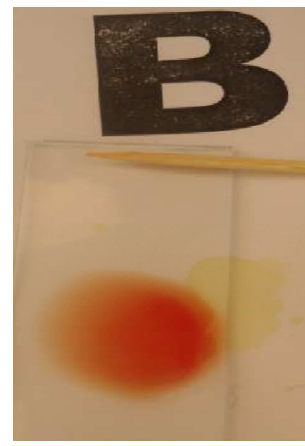

B

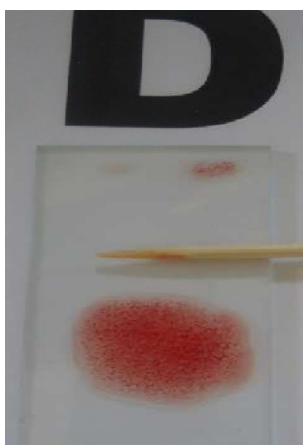

C

Figure 8.Positive blood group sample.

Figure 8 (A, B, C) shows the A Positive blood group sample on adding Antigen-A, Antigen-B and Antigen-D respectively. When Antibody A, Antibody B and Antibody D was added on the positive A blood type, the blood sample on slide $\mathrm{A}$ and $\mathrm{C}$ was form aggregates (agglutinate) butthe blood sample found on slideB remain fluid (No aggregates).

B.A Negative Group

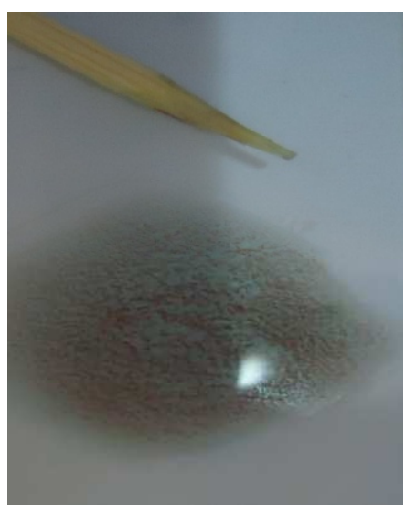

Figure 9 (A, B, C) shows the A Negative blood group sample on adding Antigen-A, Antigen-B and Antigen-D respectively. When Antibody A, Antibody B and Antibody D was added on the positive A blood type, the blood sample on slide A was form clump (agglutinates) butthe two blood sample found on slideBand $\mathrm{C}$ remain fluid (No clump).
A

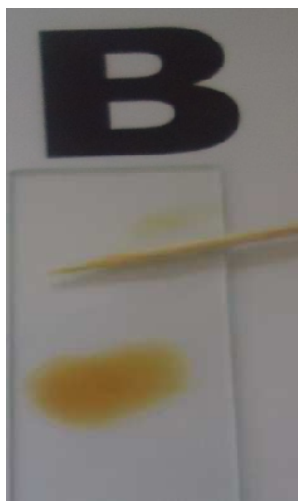

B

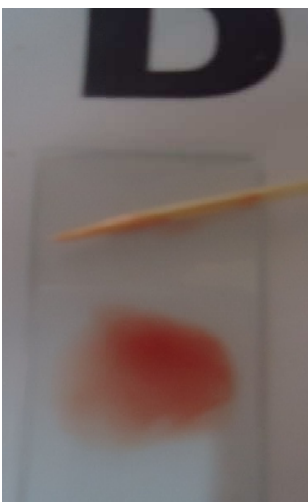

C

Figure 9. A Negative blood group sample. 


\section{B Positive Group}

Figure $10(\mathrm{~A}, \mathrm{~B}, \mathrm{C})$ shows the B Positive blood group sample on adding Antigen-A, Antigen-B and Antigen-D respectively. When Antibody A, Antibody B and Antibody D was added on the positive B blood type, the blood sample on slide $\mathrm{B}$ and $\mathrm{C}$ was form aggregates (agglutinates) buttheblood sample found on slide A remain fluid (No aggregates).
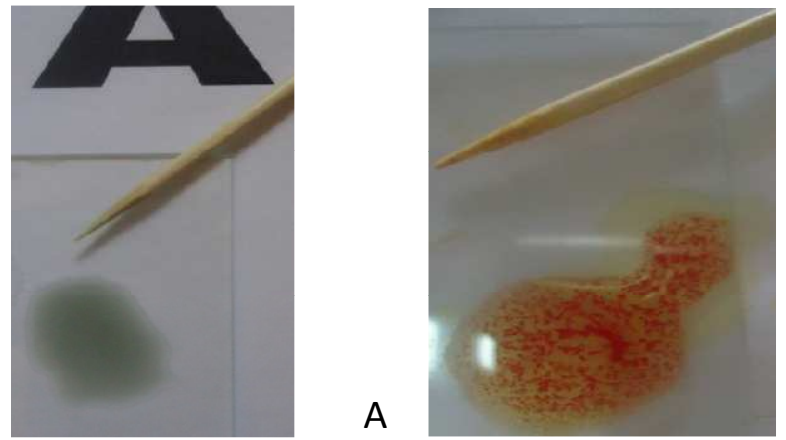

A

B

Figure 10. B Positive blood group samples.

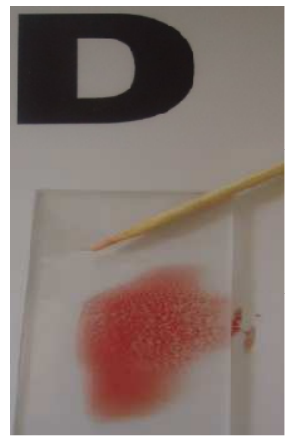

C

\section{D.B Negative Group}

Figure 11(A, B, C) shows the B Negative blood group sample on adding Antigen-A, Antigen-B and Antigen-D respectively. When Antibody A, Antibody B and Antibody D was added on the positive B blood type, the blood sample only on slide Bwas form aggregates (agglutinates) butthe two blood sample found on slide $\mathrm{A}$ and $\mathrm{C}$ remain fluid (No aggregates).

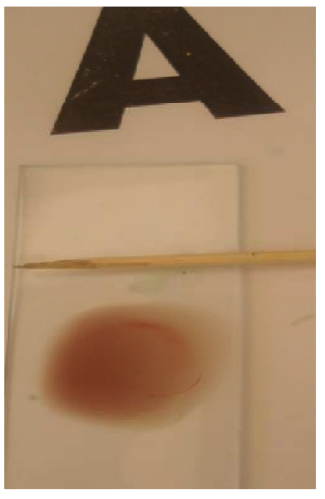

A

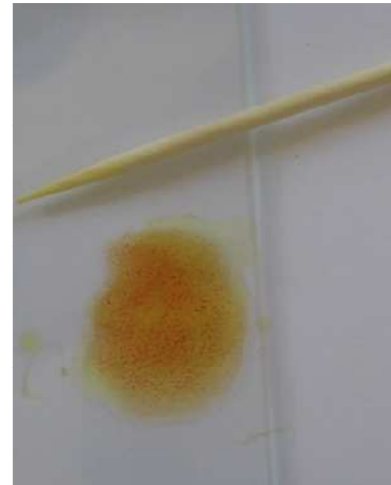

B

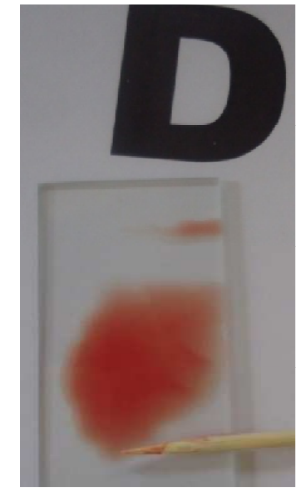

Figure 11. B Negative blood group samples.

\section{E.AB Positive Group}

Figure $12(\mathrm{~A}, \mathrm{~B}, \mathrm{C})$ shows the $\mathrm{AB}$ Positive blood group sample on adding Antigen-A, Antigen-B and Antigen-D respectively. When Antibody A, Antibody B and Antibody D was added on the positive $\mathrm{AB}$ blood type, all blood samplefound on slide A, B and Cwas form aggregates (agglutinates).
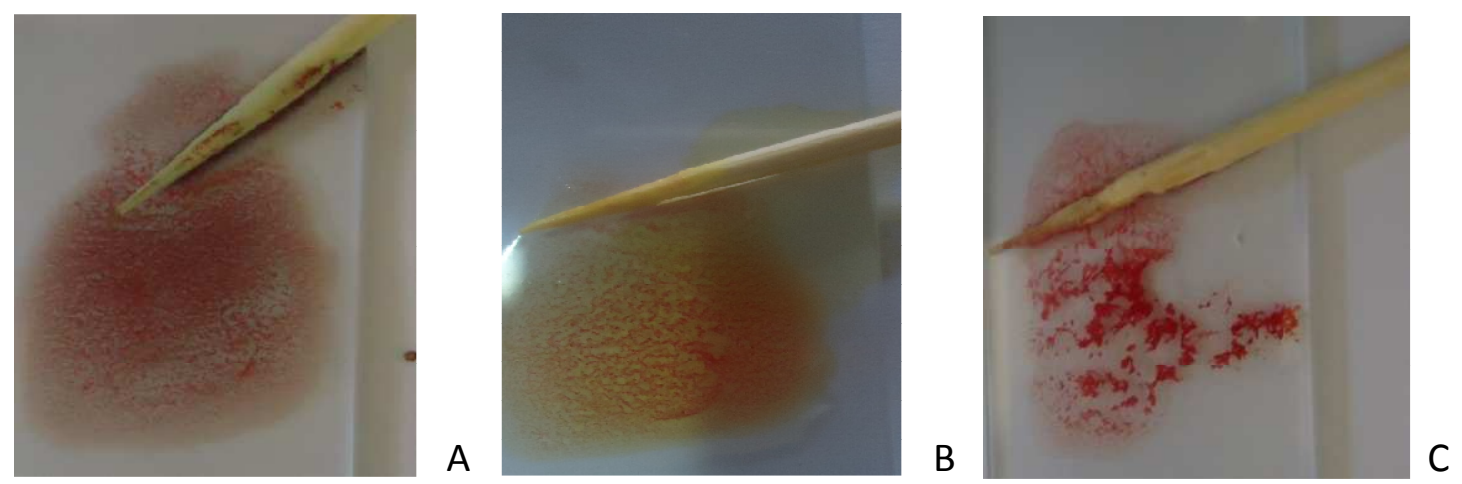

Figure 12. AB Positive blood group sample.

\section{F.AB Negative Group}

Figure 13 (A, B, C)showstheABNegativebloodgroup sampleonaddingAntigen-A,Antigen-BandAntigen-D respectively. When Antibody A, Antibody B and Antibody D was added on the negative $A B$ blood type, the blood sample on slide $\mathrm{A}$ and $\mathrm{B}$ was form aggregates (agglutinates) 
buttheblood sample found on slide C remain fluid (No aggregates).

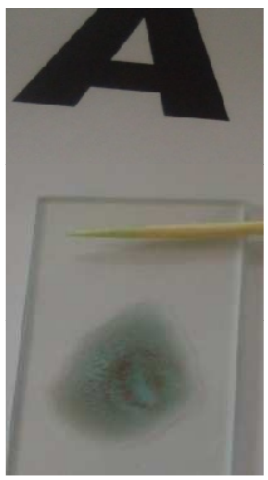

A

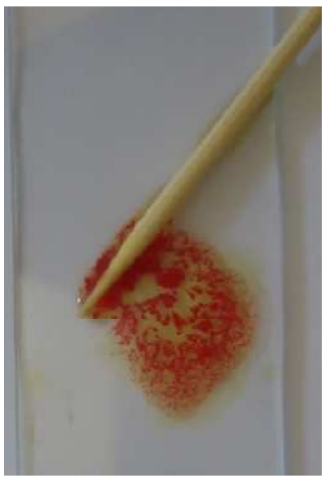

B

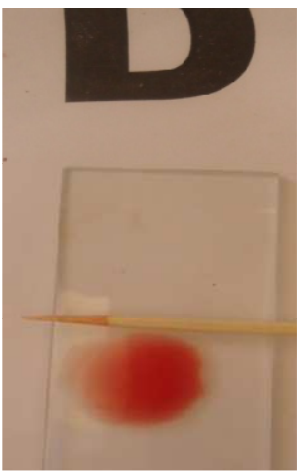

C

\section{G.O Positive Group}

Figure 14 (A, B, C) shows the O Positive blood group sample on adding Antigen-A, Antigen-B and Antigen-D respectively. When Antibody A, Antibody B and Antibody D was added on the positive O blood type, the blood sample found only on slide $\mathrm{C}$ was form aggregates (agglutinates) butthetwo blood sample found on slide A and B remain fluid (No aggregates).

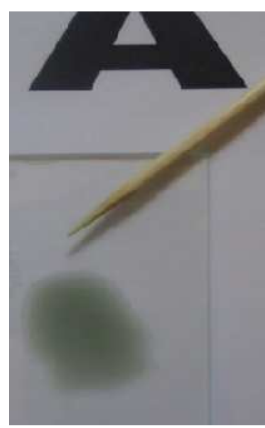

A

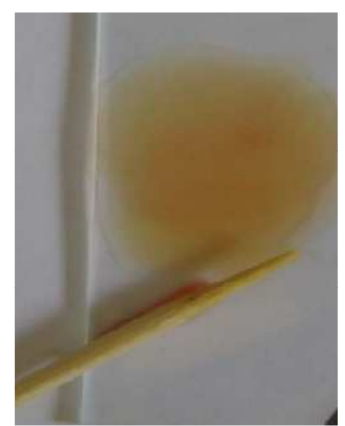

B

Figure 14. O Positive blood group sample

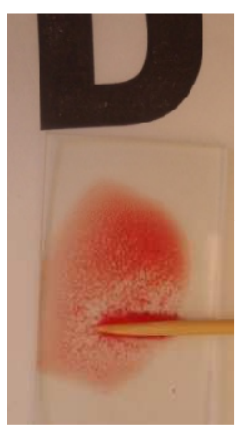

\section{C}

\section{H.O Negative Group}

Figure 15 (A, B, C) shows the O Negative blood group sample on adding Antigen-A, Antigen-B and Antigen-D respectively. When Antibody A, Antibody B and Antibody D was added on the negative $\mathrm{O}$ blood type, all blood sample found on slide A, B and C was remain fluid (No aggregates).

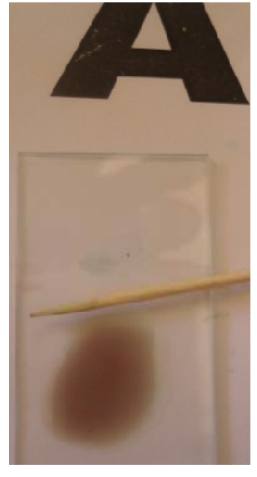

A

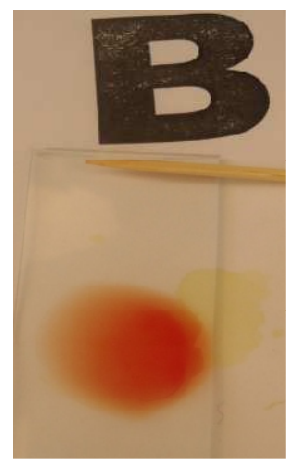

B

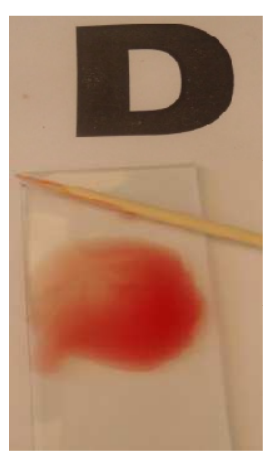

Figure 15. O Negative blood group sample.

\subsection{Ethical Clearance}

The study protocol was reviewed and approved by the Ethical Review Committee of Department of Biology, Dilla University. Written informed consent was obtained from all study participants who participated in the study after explaining the purpose and objective of the study.

\subsection{Statistical Analysis}

Data was analyzed using SPSS software (version 13.0,Chicago, IL, USA) and SISA software. Datawas expressed in percentage through graph, figure and tubular. 


\section{Results and Discussion}

The different types and distribution of $\mathrm{ABO}$ and $\mathrm{Rh}$ blood group system recorded in the 6 state and one administrate represent students at Dilla University students at 2014 are shown in Table 1and 2. Percentage distribution of the ABO blood group types among the students were 55 (26.32\%), 55 $(26.32 \%), 6(2.87 \%)$ and $93(44.49 \%)$ blood group A, B, $\mathrm{AB}$ and $\mathrm{O}$, respectively. The most prevalent blood group was type O (44.49\%) followed by A (26.32\%), B (26.32\%), and AB $(2.87 \%)$ as shown in Table 1 . There are differences in frequency distribution of the blood group (ABO) among the ethnic groups and administrate of the students at Dilla University. Blood group $\mathrm{O}$ has the highest frequency while blood group $\mathrm{AB}$ has the lowest frequency as shown in Table 1 .

In the previous study reports, theEthiopians $\mathrm{ABO}$ blood group, the distribution of type O, 40\%; type A, 31\%; type B, 23\%; and type $\mathrm{AB} ; 6 \%$ [21]. Many other studies have shown that blood group $\mathrm{O}$ was the most common blood group and blood group $\mathrm{AB}$ was the least common blood group in different ethnic groups [22]. For instance, in AfricanAmerican ABO blood group, the distribution of type O, 46\%; type A, 27\%; type B, 20\%; and type AB; $7 \%$. In Caucasians in the United State, the distribution is type O, 47\%; type A, $41 \%$; type B, $9 \%$; type AB, 3\%. Also, among Western Europeans, type O, $46 \%$; type A, $42 \%$; type B, $9 \%$; and type $\mathrm{AB}, 3 \%[11,12]$. Thus, the gene segregation for $\mathrm{ABO}$ systems always followed a particular pattern for its distribution in different ethnic group with exceptional cases.

\subsection{Percentage Distribution of the ABO Blood Group Types in the Six Ethnic Groups and One Administrative of Dilla University Students}

Of the 76 blood samples determined their blood type category, there were $15(19.73 \%), 15(19.73 \%), 3(3.95 \%), 19$ $(25.00 \%)$ and $7(9.21 \%), 6(7.89 \%), 0(0 \%), 11(14.47 \%)$ blood group $\mathrm{A}, \mathrm{B}, \mathrm{AB}$ and $\mathrm{O}$ male and female sex categories, respectively students came from Amhara state indicated Table 1. Similarly, O blood group has the highest overall percentage frequency $(67.26 \%)$ among a Nigerian population while $\mathrm{AB}$ blood group has the least overall percentage frequency $(3.10 \%)$ [23]. In Nigeria, among 7653 individuals in Ogbomoso, Oyo State, 50\% had type O,type A, 22.9\%; type $\mathrm{B}, 21.3 \%$ and type $\mathrm{AB}, 5.9 \%[6]$.

Of the 71 blood samples determined their blood type category, there were $13(18.31 \%), 9(1.26 \%), 0$ (0\%), 18 $(25.35 \%)$ and 7 (9.85\%), 7 (9.85\%), 1 (1.41\%), 16 $(22.54 \%)$ blood group A, B, AB and $\mathrm{O}$ male and female sex categories, respectively students came from SNNP state as indicated Table 1. Akinnuga [24] had reported that the students were $26.9 \%$ A blood type, $16.1 \%$ B blood type, $4.2 \%$ AB blood type and $52.9 \%$ O blood type.

Of the 47 blood samples determined their blood type category, there were $6(12.76 \%), 10(21.27 \%), 2(4.25 \%)$, $16(34.04 \%)$ and $3(6.38 \%) 5(10.64 \%), 0(0 \%), 5$ (10.64\%) blood group A, B, AB and O male and female sex categories, respectively students came from Oromia state indicated Table 1. Patel [25] had reported that it can be seen that $39.40 \%$ were detected to be having B blood group followed by $\mathrm{O}$ group $30.79 \%$, A group $21.94 \%$ and $\mathrm{AB}$ group $7.86 \%$.

Of the 4 blood samples determined their blood type category, there were $4(100 \%)$, blood group $\mathrm{O}$ and only male sex category, students came from Gambela Peoples state indicated Table 1.Of the 3 blood samples determined their blood type category, there were $1(33.33 \%)$ and 2 (66.67) blood group B and $\mathrm{O}$ and both female sex category, students came from Tigray state indicated Table 1.Of the 1 blood samples determined her blood type category, there was $1(100 \%)$, blood group A and female sex category, students came from Benshangul-Gumaz state indicated Table 1. Patel [25] had reported that regarding female, the total $\mathrm{Rh}$ blood group the rates were $92.92 \% \mathrm{Rh}$ - positive and $7.08 \% \mathrm{Rh}$ negative.

Of the 7 blood samples determined their blood type category, there were $1(14.28 \%) 1(14.28 \%) 0(0 \%), 1$ $(14.28 \%)$ and $2(28.57 \%) 1(14.28 \%) 0$ ( $0 \%) 1(14.28 \%)$ blood group $\mathrm{A}, \mathrm{B}, \mathrm{AB}$ and $\mathrm{O}$ male and female sex categories, respectively students came from Addis Ababa administrate indicated Table 1. Similarly Bakare [26] report showed that $22.9 \%$ were blood group A, 21.3\% were blood group B, and $5.9 \%$ was blood group $\mathrm{AB}$ and $50.0 \%$ were blood group $\mathrm{O}$.

Table 1. Percentage distribution of the ABO blood group types in the Dilla University among 209 Voluntary students.

\begin{tabular}{|c|c|c|c|c|c|c|}
\hline Ethnic groups and administrative & Sex & $\mathbf{A}(\%)$ & B (\%) & AB (\%) & $\mathbf{O}(\%)$ & Total \\
\hline \multirow{2}{*}{ Amhara } & Male & $15(19.73)$ & $15(19.73)$ & $3(3.95)$ & $19(25.00)$ & 52 \\
\hline & Female & $7(9.21)$ & $6(7.89)$ & - & $11(14.47)$ & 24 \\
\hline SNNP & Male & $13(18.31)$ & $9(1.26)$ & - & $18(25.35)$ & 40 \\
\hline \multirow{2}{*}{ Oromia } & Male & $6(12.76)$ & $10(21.27)$ & $2(4.25)$ & $16(34.04)$ & 33 \\
\hline & Female & $3(6.38)$ & $5(10.64)$ & - & $5(10.64)$ & 14 \\
\hline Gambela Peoples & Male & - & - & - & $4(100)$ & 4 \\
\hline \multirow{2}{*}{ Tigray } & Male & - & - & - & - & - \\
\hline & Female & - & $1(33.33)$ & - & $2(66.67)$ & 3 \\
\hline \multirow{2}{*}{ Benshangul-Gumaz } & Male & - & - & - & - & - \\
\hline & Female & $1(100)$ & - & - & - & 1 \\
\hline \multirow{2}{*}{ Addis Ababa } & Male & $1(14.28)$ & $1(14.28)$ & - & $1(14.28)$ & 3 \\
\hline & Female & $2(28.57)$ & $1(14.28)$ & - & $1(14.28)$ & 4 \\
\hline Total & Both sex & $55(26.32)$ & $55(26.32)$ & $6(2.87)$ & $93(44.49)$ & 209 \\
\hline
\end{tabular}




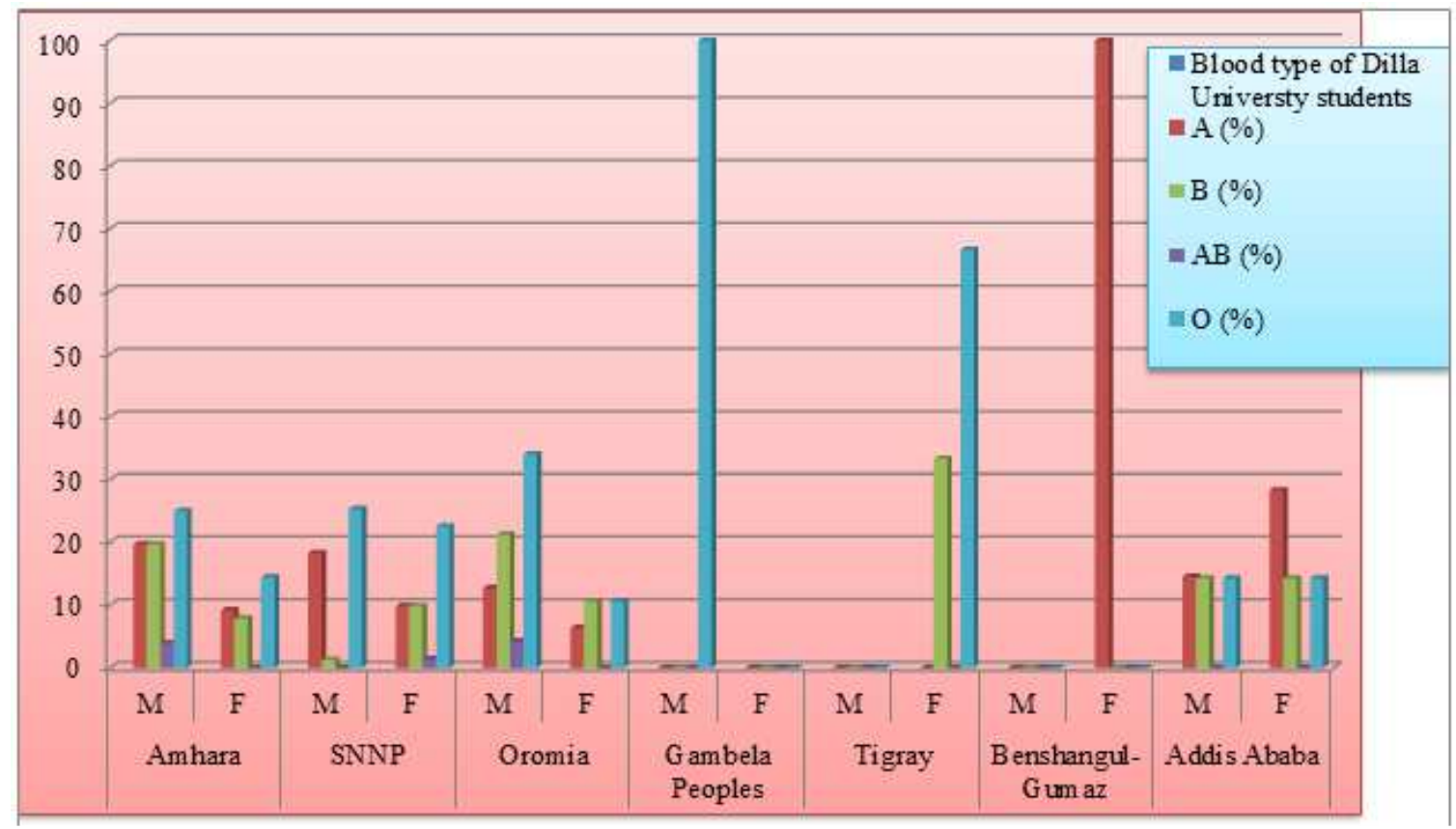

Figure 16. Percentage of blood type distribution among six ethnic groups and one administrative of Dilla University students.

\subsection{Percentage of Blood Type Distribution Among Dilla University Students}

Students came from Amhara state had highest O (25.00\%) and $(14.47 \%)$ blood group on both sex male and female respectively. Students came from SNNP state had highest $\mathrm{O}$ $(25.35 \%)$ and $(22.54 \%)$ blood group on both sex male and female respectively. Students came from Oromia state had highest O (34.04\%) and (10.64\%) blood group on both sex male and female respectively. Students came from Addis Ababa administrate had highest A (28.57\%) blood group on female sex. Students came from Gambela Peoples state their number are few and got only four male students, their blood type were O $(100.00 \%)$. Students came from BenshangulGumaz state their number are few and got only one female student, her blood type was A $(100.00 \%)$. Students came from Tigray state had highest $\mathrm{O}(66.67 \%)$ blood group having female sex as indicated Figure 16.Bakare [26] report showed that the highest blood group $46.3 \%$ were blood group O, $24.7 \%$ were blood group $\mathrm{B}, 23.6 \%$ were blood group $\mathrm{A}$ and the least blood group $5.4 \%$ were blood group $\mathrm{AB}$ at Baptist Medical Centre.

Table 2. Rh blood group distribution amongethnic groups and administrative of 209 voluntary Dilla University students.

\begin{tabular}{|c|c|c|c|c|c|c|}
\hline Ethnic groups and administrative & Rh-blood groups & $\mathbf{A}(\%)$ & B (\%) & AB (\%) & O (\%) & Total \\
\hline \multirow{2}{*}{ Amhara } & Positive & $22(28.94)$ & $21(27.63)$ & $2(2.63)$ & $24(31.57)$ & 69 \\
\hline & Negative & - & - & $1(1.32)$ & $6(7.89)$ & 7 \\
\hline \multirow{2}{*}{ SNNP } & Positive & $20(28.16)$ & $14(19.72)$ & - & $28(39.44)$ & 62 \\
\hline & Negative & - & $2(2.82)$ & $1(1.41)$ & $6(8.45)$ & 9 \\
\hline \multirow{2}{*}{ Oromia } & Positive & $9(19.15)$ & $13(27.66)$ & $2(4.26)$ & $19(40.43)$ & 43 \\
\hline & Negative & - & $2(4.25)$ & - & $2(4.25)$ & 4 \\
\hline Gambela Peoples & Positive & - & - & - & $4(100)$ & 4 \\
\hline \multirow{2}{*}{ Tigray } & Positive & - & - & - & $2(66.67)$ & 2 \\
\hline & Negative & - & $1(33.33)$ & - & - & 1 \\
\hline \multirow{2}{*}{ Benshangul-Gumaz } & Positive & $1(100)$ & - & - & - & 1 \\
\hline & Negative & - & - & - & - & - \\
\hline \multirow{2}{*}{ Addis Ababa } & Positive & $3(42.85)$ & $1(14.28)$ & - & $2(28.57)$ & 6 \\
\hline & Negative & - & $1(14.28)$ & - & - & 1 \\
\hline Total & Both Rh-blood group & $55(26.32)$ & $55(26.32)$ & $6(2.87)$ & $93(44.49)$ & 209 \\
\hline
\end{tabular}

\subsection{Rh Blood Group Distribution Among Ethnic Groups and Administrative}

Table 2 showed the frequency distributions of ABO blood group and ethnic groups and administrate based on $\mathrm{Rh}$ blood group. The percentage of distribution of the $\mathrm{ABO}$ bloods group and ethnic groups and administrate varies significantly based on Rh blood group. The most prevalent blood group was positive blood type $(90.78 \%)$, followed by negativeblood type (9.21\%), in the Amhara state of the studentssimilarly, in the SNNP state of students was positive blood type (87.32\%) followed by negative blood type (12.68\%) (Table 2$)$. On the 
other hand, the highest blood type in the Oromia state of students was positive type $(91.50 \%)$ followed by $(8.50 \%)$ as indicated in Table 2.Bakare [25] report showed that the highest Rh- blood types were Rh-positive $95.00 \%$ and the Rh-blood types $5.00 \%$ were Rh-negative at Baptist Medical Centre.

Table 3. Rh Negative blood group distribution among ethnic groups and administrative of 209 voluntary Dilla University students.

\begin{tabular}{|c|c|c|c|c|c|c|}
\hline Ethnic groups and administrative & Sex & $\mathrm{A}^{-}(\%)$ & $\mathrm{B}^{-}(\%)$ & $\mathrm{AB}^{-}(\%)$ & $\mathrm{O}^{-}(\%)$ & Total \\
\hline \multirow{2}{*}{ Amhara } & Male & - & - & $1(12.50)$ & $5(62.50)$ & 6 \\
\hline & Female & - & - & - & $2(25.00)$ & 2 \\
\hline \multirow{2}{*}{ SNNP } & Male & - & - & - & $5(55.56)$ & 5 \\
\hline & Female & - & $2(22.22)$ & $1(11.11)$ & $1(11.11)$ & 4 \\
\hline \multirow{2}{*}{ Oromia } & Male & - & $1(25.00)$ & - & $2(50.00)$ & 3 \\
\hline & Female & - & $1(25.00)$ & - & - & 1 \\
\hline Gambela Peoples & Male & - & - & - & - & - \\
\hline \multirow{2}{*}{ Tigray } & Male & - & - & - & - & - \\
\hline & Female & - & $1(100.00)$ & - & - & 1 \\
\hline \multirow{2}{*}{ Benshangul-Gumaz } & Male & - & - & - & - & - \\
\hline & Female & - & - & - & - & - \\
\hline \multirow{2}{*}{ Addis Ababa } & Male & - & - & - & - & - \\
\hline & Female & - & $1(100.00)$ & - & - & 1 \\
\hline Total & Both sex & - & $6(26.08)$ & $2(8.69)$ & $15(65.22)$ & 23 \\
\hline
\end{tabular}

\subsection{Rh-Negative Blood Groups Distribution}

Table 3 showed the frequency distributions of ABO blood group and ethnic groups and administrate based on Rh blood group. The percentage of distribution of the ABO bloods group and ethnic groups and administrate varies significantly based on Rh blood group.

The most prevalent blood group was type $\mathrm{O}^{-}(62.50 \%)$, followed by $\mathrm{O}^{-}(25.00 \%)$,both male female respectively while only one $\mathrm{AB}^{-}(12.50 \%)$ female in the Amhara state students as shown in Table 3. While, the most prevalent blood group was type $\mathrm{O}^{-}(55.56 \%)$ followed by $\mathrm{B}^{-}(22.22 \%)$ with male and female sex in the SNNP state. On the other hand, the highest blood group in the Oromia state of students was $\mathrm{O}^{-}(50.00 \%)$ as indicated in Table 3.Bakare [26] report showed that the highest Rh- blood types were Rh-positive $95.00 \%$ and the Rh-blood types $5.00 \%$ were Rh-negative at Baptist Medical Centre.

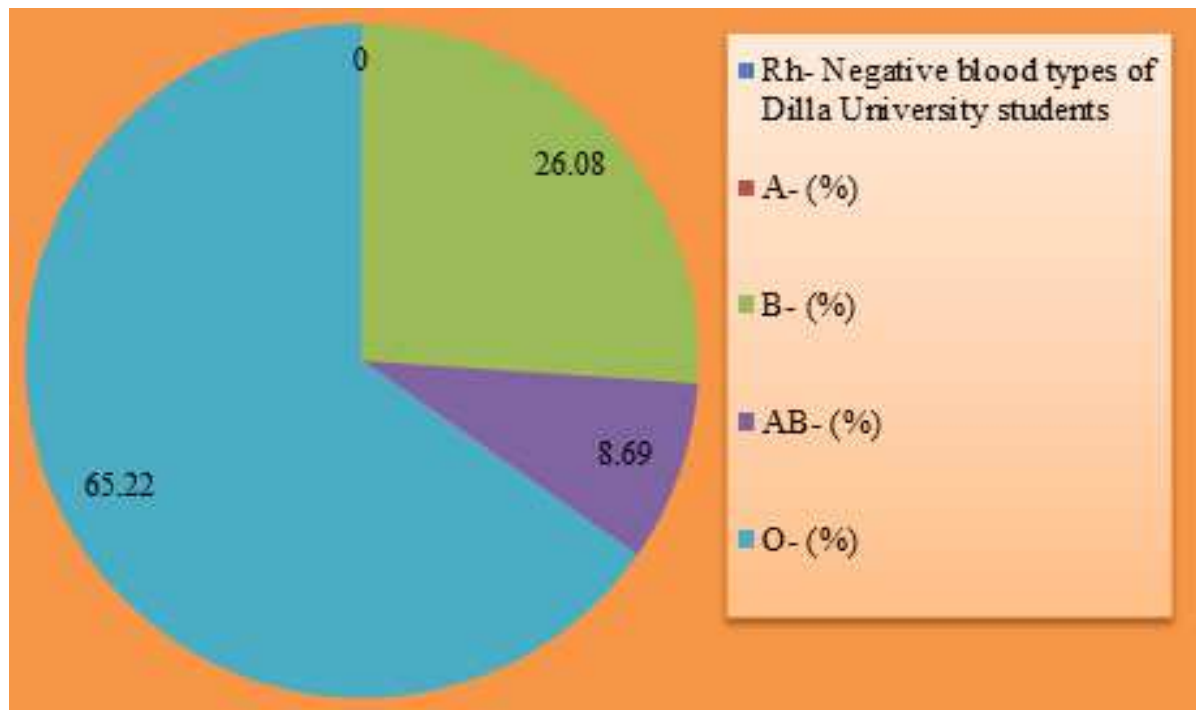

Figure 17. Percentage of Rh-negative blood groups distribution among students in Dilla University.

\subsection{Distribution ofRh Blood Among Dilla University Students}

The most prevalent $\mathrm{Rh}$-negative blood groups among students were type $\mathrm{O}^{-}(65.22 \%)$ followed by $\mathrm{B}^{-}(26.08 \%)$, $\mathrm{AB}^{-}(26.34 \%)$, and no Ablood group as shown in Figure 17.Bakare et al. (2005), report showed that the highest Rhblood types were Rh-positive $96.70 \%$ and the Rh-blood types $3.30 \%$ were Rh-negative. Patel [25] had reported that looking at the rhesus grouping, on male sex, $7.38 \%$ were $\mathrm{Rh}$ positive $\mathrm{AB}$ Blood type and remaining $0.45 \%$ were $\mathrm{Rh}$ negative $\mathrm{AB}$ Blood type .

\subsection{Rh-Positive Blood Groups Distribution}

Table 4 showed the frequency distributions of ABO blood group and ethnic groups and administrate based on Rh-blood group. The percentage of distribution of the $\mathrm{ABO}$ bloods 
group and ethnic groups and administrate varies significantly based on $\mathrm{Rh}$ blood group.

The most prevalent blood group were type $\mathrm{O}^{+}, \mathrm{B}^{+}, \mathrm{A}^{+}$and $25.00 \%, 22.05 \%, 20.58 \%$ male and $\mathrm{A}^{+}, \mathrm{B}^{+}, \mathrm{AB}^{+}$and $11.76 \%$, $8.82 \%, 8.82 \%$ female respectivelystudents came from Amhara state as shown in Table 4. The most prevalent blood group were type $\mathrm{O}^{+}, \mathrm{A}^{+}, \mathrm{B}^{+}, 25.80 \%, 19.35 \% 11.29 \%$, and $19.35 \%, 12.90 \%, 11.29 \%$ bothmale and female respectively students came from SNNP state While there is no $\mathrm{AB}^{+}$blood type in both sex in the present study ofblood sampletaken from SNNP state of studentsas shown in Table 4.The prevalent Rh-positive blood groups among students were type, $\mathrm{A}^{+}, \mathrm{B}^{+}, \mathrm{O}^{+}$and $\mathrm{A}^{+}, \mathrm{O}^{+}, 16.66 \%$ and $33.33 \%, 16.66 \%$ both male and female students came from Addis Ababa administrate respectively. Patel [25] had reported that looking at the rhesus grouping, on an average, $95.05 \%$ were $\mathrm{Rh}$ positive and remaining $4.95 \%$ were Rh negative. Male Rhblood group $95.15 \%$ were $\mathrm{Rh}$ positive whereas remaining male $4.85 \%$ ) were $\mathrm{Rh}$ negative. Patel [25] had reported that looking at the rhesus grouping, on female sex, $21.67 \%$ were $\mathrm{Rh}$ positive A blood type and remaining $0.83 \%$ were $\mathrm{Rh}$ negative A blood type.

Table 4. Rh Positive blood group distribution among ethnic groups and administrative of 209 voluntary Dilla University students.

\begin{tabular}{|c|c|c|c|c|c|c|}
\hline Ethnic groups and administrative & Sex & $\mathrm{A}^{+}(\%)$ & $\mathbf{B}^{+}(\%)$ & $\mathrm{AB}^{+}(\%)$ & $\mathbf{O}^{+}(\%)$ & Total \\
\hline \multirow{2}{*}{ Amhara } & Male & $14(20.58)$ & $15(22.05)$ & $2(2.94)$ & $17(25.00)$ & 48 \\
\hline & Female & $8(11.76)$ & $6(8.82)$ & - & $6(8.82)$ & 20 \\
\hline \multirow{2}{*}{ SNNP } & Male & $12(19.35)$ & $7(11.29)$ & - & $16(25.80)$ & 35 \\
\hline & Female & $8(12.90)$ & $7(11.29)$ & - & $12(19.35)$ & 27 \\
\hline \multirow{2}{*}{ Oromia } & Male & $6(13.95)$ & $9(20.93)$ & $2(4.65)$ & $14(32.56)$ & 31 \\
\hline & Female & $3(6.97)$ & $4(9.30)$ & - & $5(11.63)$ & 12 \\
\hline Gambela Peoples & Male & - & - & - & $4(100.00)$ & 4 \\
\hline \multirow{2}{*}{ Tigray } & Male & - & - & - & - & - \\
\hline & Female & - & - & - & $2(100.00)$ & 2 \\
\hline \multirow{2}{*}{ Benshangul-Gumaz } & Male & - & - & - & - & - \\
\hline & Female & $1(100.00)$ & - & - & - & 1 \\
\hline \multirow{2}{*}{ Addis Ababa } & Male & $1(16.67)$ & $1(16.66)$ & - & $1(16.66)$ & 3 \\
\hline & Female & $2(33.33)$ & - & - & $1(16.67)$ & 3 \\
\hline Total & Both sex & $59(31.72)$ & $49(26.34)$ & $4(2.15)$ & $78(41.94)$ & 186 \\
\hline
\end{tabular}

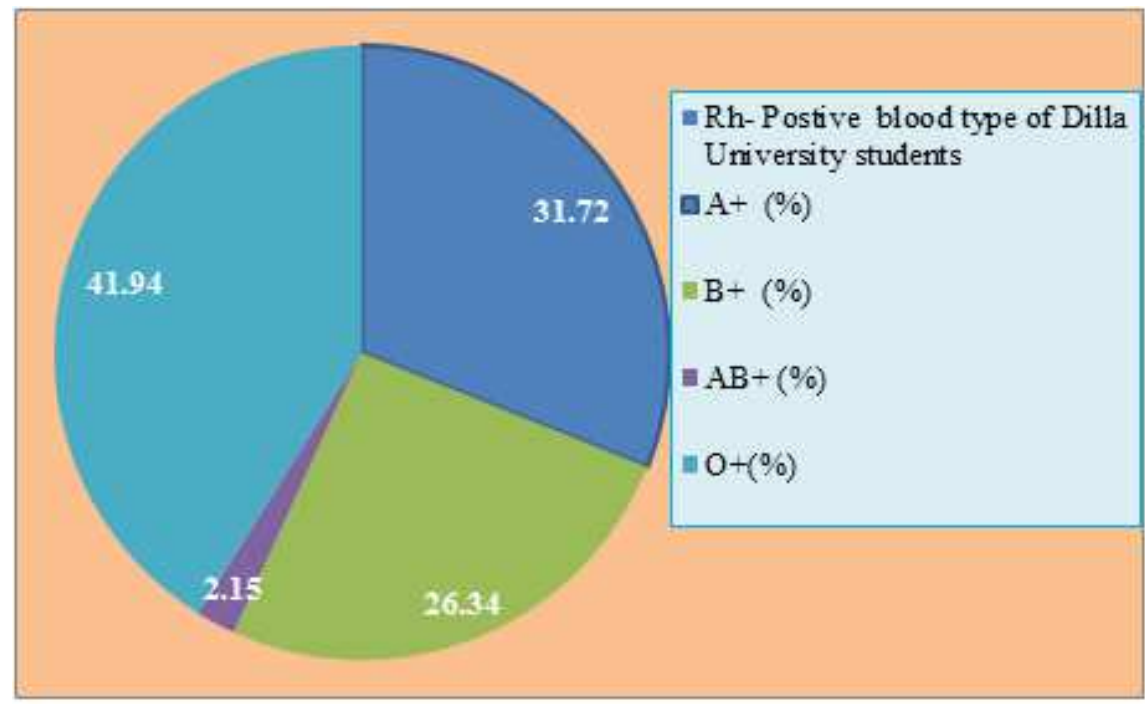

Figure 18. Percentage of Rh-positive blood groups distribution among students in Dilla University.

\subsection{Rh-Positive Blood Groups Distribution}

The most prevalent Rh-positive blood group among students were type $\mathrm{O}^{+}(41.94 \%)$ followed by $\mathrm{A}^{+}(31.72 \%)$, $\mathrm{B}^{+}(26.34 \%)$, and $\mathrm{AB}^{+}(2.15 \%)$ as shown in Figure 18. Patel [25] had reported that $95.48 \%$ were male and $4.52 \%$ were female subjects. As well as the commonest $\mathrm{ABO}$ blood group present was B $(39.40 \%)$ followed by O (30.79\%), A $(21.94 \%)$ and $\mathrm{AB}(7.86 \%)$ in blood donors. Patel [25] had reported that looking at the rhesus grouping, on female sex, $28.33 \%$ were $\mathrm{Rh}$ positive $\mathrm{O}$ blood type and remaining $2.92 \%$ were Rh negative O blood type.

\section{Conclusion}

The blood $\mathrm{ABO}$ and $\mathrm{Rh}$ blood group varies among ethnic group and administrate of Dilla University students. The relevance of having knowledge about the blood group systems among different ethnic groups in any population is enormous. The types of information obtained from the findings are useful for genetic information, genetic counseling, medical diagnosis and general and physiological 
wellbeing of individuals in a population. And also very importance during emergency and accidental healthy disorder especially, at deficient blood and again for donating.

\section{Acknowledgments}

I am grateful thanks to Dilla University, College of Natural and Computational sciences, Department of Biology who are giving these facilities to conduct this study. I extend also my thanks to Dilla University students who are voluntary to give their blood as a sample to determination their blood type and group and finally to generate this great important data.

\section{References}

[1] SaladinK.Anatomy and Physiology: The Unity of Form and Function, $3^{\text {rd }}$ Edition. The McGraw-Hill Companies, USA, 2003; Pp.679-698.

[2] Daniels G. Human Blood Groups, $2^{\text {nd }}$ ed. Blackwell Science, 2002.

[3] Worlledge S, Ogiemudia SE, ThomasCO,Ikoku BN, Luzzutto L. Blood group antigens and antibodies in Nigeria. Ann Trop Med Parasitol, 1974; 68: 249-264.

[4] Seeley RR, Stephens TD, Tate P. Anatomy and Physiology. $4^{\text {th }}$ Edn., The McGraw Hill Companies, Inc., USA, 1998; pp: 1098.

[5] Davey WW, Elebute EA. ABO blood groups in relation to duodenal ulceration among the Yorubas of Western Nigeria. Gut, 1963; 4:367.

[6] Bakare AA, Azeez MA, Agbolade JO. Gene frequencies of $\mathrm{ABO}$ and Rhesus blood groups and haemoglobin variants in Ogbomoso, south-west Nigeria. Afr J Biotechnol, 2006; $5: 224-229$.

[7] Jeremiah ZA. Abnormal haemoglobin variants, $\mathrm{ABO}$ and $\mathrm{Rh}$ blood groups among student of African descent in Port Harcount, Nigeria. Afr Health Sci, 2006; 6:177-181.

[8] Garratty G. Relationship of blood groups to disease: do blood group antigens have a biological role? Rev Med Inst Mex Seguro Soc, 2005; 43:113-121.

[9] LandsteinerK. Kenntnisderantifermentativen,lytischenundagglutinierenden Wirkungen des Blutserums und der Lymphe. (In German). Zentralbl Bakteriol, 1900; 27: 357-362.

[10] Fareed M, Hussain R, Shah A, Afzal M. A1A2BO and Rh gene frequencies among six populations of Jammu and Kashmir, India. Transfusion and Apheresis Science, 2014; 50: 247-252.

[11] Pramanik T, Pramanik S. Distribution of ABO and Rh blood groups in Nepalese students: A report. East Mediterr Health J, 2000; 6(1): 156-158.
[12] Adeyemo OA, Soboyejo OB. Frequency distribution 0f ABO, $\mathrm{RH}$ blood groups and blood genotypes among the cell biology and genetics students of University of Lagos, Nigeria. Afr J Biotechnol, 2006; 5(22): 2062-2065.

[13] Mwangi J. Blood group distribution in an urban population of patient targeted blood donors. East Afr Med J, 1999; 76(11): 615-618.

[14] OmotadeOO, Adeyemo A, AKayode CM, Falade SL, Ikpeme $\mathrm{S}$. Gene frequencies of $\mathrm{ABO}$ and $\mathrm{Rh}(\mathrm{D})$ blood group alleles in a healthy infant population in Ibadan, Nigeria. West Afr J Med, 1999; 18: 294-297.

[15] EstridgeBH, Reynolds AP, WaltersNJ. Basic Medical Laboratory Techniques, $4^{\text {th }}$ ed. Thomson Learning, 2000.

[16] Khan MS, Subhan F, Tahir F, Kazi BM, Dil AS, Sultan S. Prevalence of blood groups and $\mathrm{Rh}$ factor in Bannu region NWFP (Pakistan). Pak J Med Res, 2004; 43 (1): 8-10.

[17] Khaliq MA, Khan JA, Shah H, Khan SP. Frequency of ABO and $\mathrm{Rh}(\mathrm{D})$ blood group in Hazara division (Abbottabad). Pak J Med Res, 1984; 23: 102-103.

[18] BarraganA, Kremsner PG, Wahlgren M, Carlson J. Blood group A antigen is a coreceptor in Plasmodium falciparum rosetting. Infect Immun, 2000; 68:2971-2975.

[19] ZoysaD. The distribution of ABO and Rhesus (Rh) blood groups in Sri Lanka. Ceylon medical journal, 1985; 30:37-41.

[20] Dacie JV, Lewis SM. Practical Haematology. In: Lewis, S.M., B.J. Bain, I. Bates, (Eds.), 9 ${ }^{\text {th }}$ Edn., Churchill Livingstone, Harcourt Publishers Limited, London, 2001; pp: 444-451.

[21] Misganaw Birhaneselassie. Immunohaematology, Debub University, 2004.

[22] Nwauche CA, Ejele OA. $\mathrm{ABO}$ and rhesus antigens in a cosmopolitan Nigeria population. Niger J Med, 2004; 13(3): 263-266.

[23] Alimba CG, Adekoya KO, Oboh BO. Prevalence and gene frequencies of phenylthiocarbamide (PTC) taste sensitivity, $\mathrm{ABO}$ and rhesus factor $(\mathrm{Rh})$ blood groups, and haemoglobin variants among a Nigerian population. Egyptian Journal of Medical Human Genetics, 2010; 11:153-158.

[24] AkinnugaBO, Amosu AM, Ugwah GU. Distribution of ABO and Rh Blood Groups among Major Ethnic Groups of Medical Students of Madonna University Teaching Hospital, Elele, Nigeria. Asian Journal of Medical Sciences, 2011; 3(3): 106109.

[25] PatelPA, Patel SP, Shah JV, Oza HV. Frequency and distribution of blood groups in blood donors in western ahmedabad a hospital based study. National Journal of Medical Research, 2012; 2 (2): 202-206.

[26] Bakare AA, Azeez MA, Agbolade JO. Gene frequencies of $\mathrm{ABO}$ and rhesus blood groups and haemoglobin variants in Ogbomoso, south-west Nigeria. Afr J Biotechnol, 2005; 5(3): 224-229. 